Original Paper http://ajol.info/index.php/ijbes http://indexmedicus.afro.who.int

\title{
Impact of road construction on the distribution of Crocodylus suchus (Étienne Geoffroy Saint-Hilaire 1807) in urban park Bangr-Weoogo (Burkina Faso)
}

\author{
Ilassa OUEDRAOGO ${ }^{1 *}$, Idrissa OUEDRAOGO ${ }^{2}$., Noëllie W. KPODA ${ }^{1}$, \\ Adama OUEDA $^{1}$, Victor BANCE ${ }^{1}$, Justine KABORE ${ }^{1}$ and Gustve B. KABRE ${ }^{1}$ \\ ${ }^{1}$ Laboratoire de Biologie et Écologie Animales, Université Joseph KI-ZERBO, Burkina Faso, 03 BP 7021 \\ Ouagadougou 03. \\ ${ }^{2}$ Centre Universitaire Polytechnique de Dori/Université Ouaga 2, 12 BP 417 Ouagadougou 12, \\ Burkina Faso. \\ *Corresponding author; E-mail: ilorescap@yahoo.fr; Tel: (+226) 767155 12/78 295971
}

\section{ACKNOWLEDGEMENTS}

We are grateful to the project "Africa for Innovation, Mobility, Exchange, Globalization and Quality" (AFIMEGQ), for financial support in realization of this work. And National Office of protected areas (OFINAP), for their approval and support, as well as all park staff to have a great interest in our work.

\begin{abstract}
In contrast to other anthropogenic activities, little is known about impact of road construction on reptile's distribution in urban areas. Therefore, the present study aimed at quantifying impact of road construction on $C$. suchus distribution. It was conducted from February 2016 to May 2018, in the urban Park Bangr-weoogo. $C$. suchus populations were counted day by used binoculars pairs and night by spotlight. The different observations were carried on foot. Every time, we observed crocodile, we visually estimate its size class. When we couldn't appreciate the size of an individual, it was just noted as eyes only. About road works, direct observations have been done and noted. To have mapping of the dynamics of crocodile habitats in the park, aerial shots were taken during road construction. We used QGIS version 2.18.2 to establish map distribution of crocodiles. A total of 145 crocodiles including $10.34 \%$ of hatchlings, $17.93 \%$ of juveniles, $31.03 \%$ of subadults and 24.14 of adults were counted before road works. While during road work, 202 crocodiles were counted, whose $5.45 \%$ of hatchlings, $19.8 \%$ of juveniles, $30.69 \%$ of subadults and $37.62 \%$ of adults. Road work has led to a loss of crocodile habitat.
\end{abstract}

(C) 2020 International Formulae Group. All rights reserved.

Keywords: Protected area, habitat, abundance.

\section{INTRODUCTION}

Conservation of biodiversity has become a major worldwide concern (Hanski, 2005). The current loss of biodiversity is unprecedented and irreversible (Ceballos et al., 2015). The main cause is the elimination or the degradation of natural habitats around the world (Krauss et al., 2010) Burkina Faso faces problems of ecological imbalances and accelerated degradation of natural resources (Belem et al., 2018). Roads generate ecological effect which disturbs ecosystem processes and 
wildlife movements. Construction and improvement of all types of roads leads, directly or indirectly, to significant loss or degradation of aquatic ecosystems (Caro, 2015), natural habitats and increased wildlife mortality. Roads could also affect animal survivorship and behavior and thereby can act as a barrier to movement, which exacerbates habitats fragmentation (Andrews and Gibbons, 2005). Indeed, based on biology and ecology, species of amphibians and reptiles taxa occupy similar habitats and are equally vulnerable to habitat degradation (Trombulak and Frissell, 2000). Thus, synotopic species of amphibians and reptiles, semiaquatic species are correspondingly defenseless against global threats of deforestation, alterations in vegetation cover along borders of water bodies, draining of wetlands, and pollution from agricultural runoff. Although the problem of amphibian decline is a serious threat, reptiles appear to be in even greater danger of extinction worldwide (Alroy, 2015). Like many fauna years ago, biologists of conservation show concerns about reptile declines. Nevertheless, according to Shirley et al. (2014) the notable lack of information about status of reptiles in most regions has hampered full understanding and appreciation of their current plight. Without question, some reptile populations have been extirpated and numbers of some species have declined with little indication of the underlying cause clearly, a primary goal of scientists should be to clarify the global status and distribution of reptile populations. Family of Crocodylidae is represented by 24 species (Hekkala et al., 2011; Shirley et al., 2014) of which one is found in Burkina Faso, Crocodylus suchus previously named Crocodylus niloticus. The order Crocodilian are characterized as large, semi aquatic carnivores living in freshwater habitats in the tropical and warm temperate regions of the world. The urban park Bangr-Weoogo (UPBW), located in Ouagadougou, the capital of Burkina Faso, houses very diverse fauna and flora (Gnoumou et al., 2008). It is part of habitat preservation and protection of the environmental potential of Ouagadougou. The park is an outlet for draining water from the city through the channelized rivers Wemtenga and Zogona. It also embodies traditional beliefs. The Zogona river (now channelized) is a sacred river in which coexist sacred crocodile species (Gnoumou et al., 2008). In context of development of urban roads of Ouagadougou, reconstruction of urban section of the National Road $\mathrm{N}^{\circ} 4$ (RN4) are conducted. It crosses the channel of Zogona that serve for water evacuation and also for the migration of reptiles in the park. The implementation of a road project leads to disturbances in the area crossed. These disturbances, which are mainly due to site work, can cause a change in the environment because it constitutes a barrier within the territory. These barriers can constitute obstacles for the migration and distribution of aquatic fauna. Despite the provisions and regulations in force for the protection and conservation of reptiles, several threats could affect their population.

We sought to assess the impact of road construction on the abundance of crocodiles in one of the urban protected areas of Burkina Faso. A better knowledge of the faunal populations, in particular the crocodiles of the park is essential, in order to establish actions of conservation of the biodiversity. Thereby, this paper aimed at describing abundance, distribution, and impact of national road $n^{\circ} 4$ (RN4) construction on the crocodiles in the urban park Bangr-Weoogo (UPBW).

\section{MATERIALS AND METHODS}

\section{Study area and choice of survey points}

The urban park Bangr-Weoogo (UPBW) is located in the heart of the city of Ouagadougou, between $12^{\circ} 22^{\prime} 59,4^{\prime \prime} ; 12^{\circ}$ $23^{\prime} 01,7^{\prime}$ ' $\mathrm{N}$ and $1^{\circ} 30^{\prime} 10,00^{\prime \prime}$; 1 ${ }^{\circ} 37^{\prime} 12,2$ ', $\mathrm{W}$ (Gnoumou et al., 2008). It is a natural forest of more than 265 hectares (Koadima and Sarr, 2010) and located in the Nongr-masson district 
between two national roads (RN3 and RN4) (Figure 1). It is located downstream of reservoirs $n^{\circ} 1,2$ and 3 of Ouagadougou. With these reservoirs, the Bangr-Weoogo Park constitute a complex recently registered as a Ramsar site on February 2, 2019 (Ramsar, 2019). This parc has a high variety of plants and animals and is considered as a sacred space, for that reason the emperor of the Mossis practice certain rituals in the park. It is a very important site for the capital because of the important biodiversity encountered. It represents the green lung of the city and an environmental education site. The park contains fifteen species of animals including reptiles with crocodiles as the largest group. The hydrographic network consists of a river that goes through the park and receives waters from tributaries which are draining the city (Kangoye et al., 2016). The climate of Ouagadougou and Bangr-Weoogo area is characterized by one rainy season (June to September) and one dry season (October to May). The maximum temperatures range from 34 to $41{ }^{\circ} \mathrm{C}$ and the minimum from 16 to $26^{\circ} \mathrm{C}$ (Kangoye et al., 2016).

According to accessibility and the presence of water, a total of 33 points was set in the study area (Figure 2). As much as possible, points were set equidistance, $20 \mathrm{~m}$ between successive points, and their coordinates recorded with a GPS (Global Position System). Each point was marked by a physical mark to allow further survey.

\section{Environmental characteristics}

The environmental characteristics of study area were also surveyed before and during road construction. To do so, a pedestrian survey of the area. A first, observation was done before the road construction and a second observations was made during the early stage of the road. For the second survey of the environmental characteristics, we completed our observations with aerial photographs done with a drone at $250 \mathrm{~m}$ altitude and $7 \mathrm{~cm}$ of spatial resolution. As environmental characteristic, we noticed the following elements: tree mortality, canal impoundment, presence of water, water flow, the river network.

\section{Crocodile surveys}

To analyse crocodile abundance and distribution in UPBW, two types of survey were used: a diurnal survey and a nocturnal survey (nocturnal spotlight counts) accordingly to Platt et al. (2000); Santiapillai et al. (2001); Shirley et al. (2012) and Fukuda et al. (2013). We conducted two survey, one before the road construction and the second during the road construction, exactly three mouth after the beginning of the roadwork in 2016. Diurnal survey is done first from 7-12 $\mathrm{h}$ and then again from $15-18 \mathrm{~h}$. The nocturnal survey is done at night from 19-23 h. For each survey, we noted date, start and end time, surveyed distance, reservoir and other additional important remarks. We searched for crocodiles on foot along the bank. Binoculars were used to facilitate the counting of crocodiles from a distance before they fled into water from the banks or submerged. We classified each spotted crocodile by size, estimated visually, as follows in four categories: hatchlings $(<0.5 \mathrm{~m})$, juveniles $(0.5-1.0 \mathrm{~m})$, subadults $(1-1.50 \mathrm{~m})$, and adults $(>1.5 \mathrm{~m})$. individuals are classified in the category "eyes only" (Ys) when we were unable to precisely determine size.

\section{Data analysis}

The data collected were recorded into a field datasheet on a daily basis, and subsequently transferred into an excel sheet for data-basing before analysis. All statistical analyses were performed using QGIS version 2.18.2. It was used to create the distribution map of crocodiles in UPBW. Excel was used to draw age structure of crocodile populations before and during road work. 


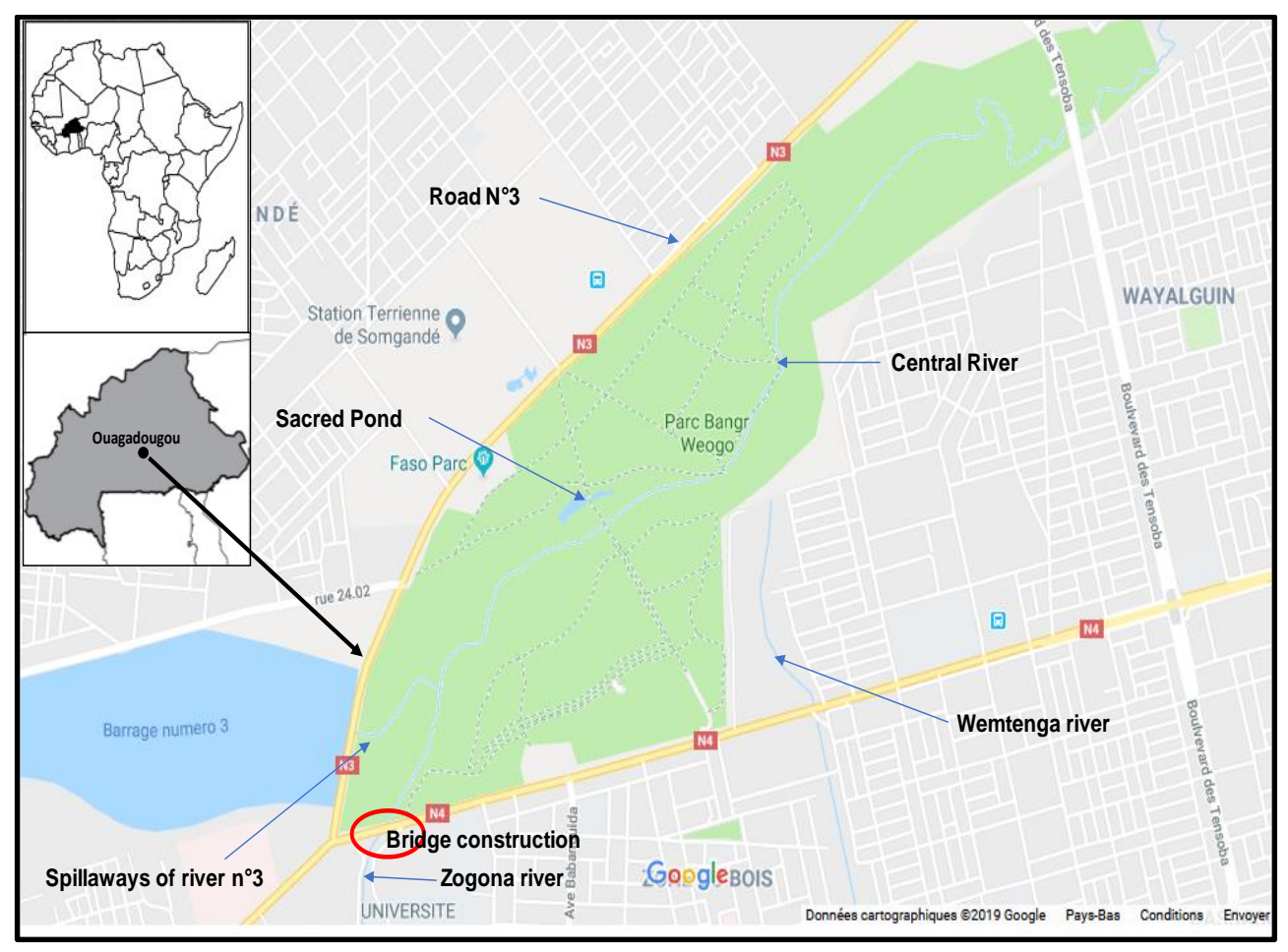

Figure 1: Map of study area (Google maps).

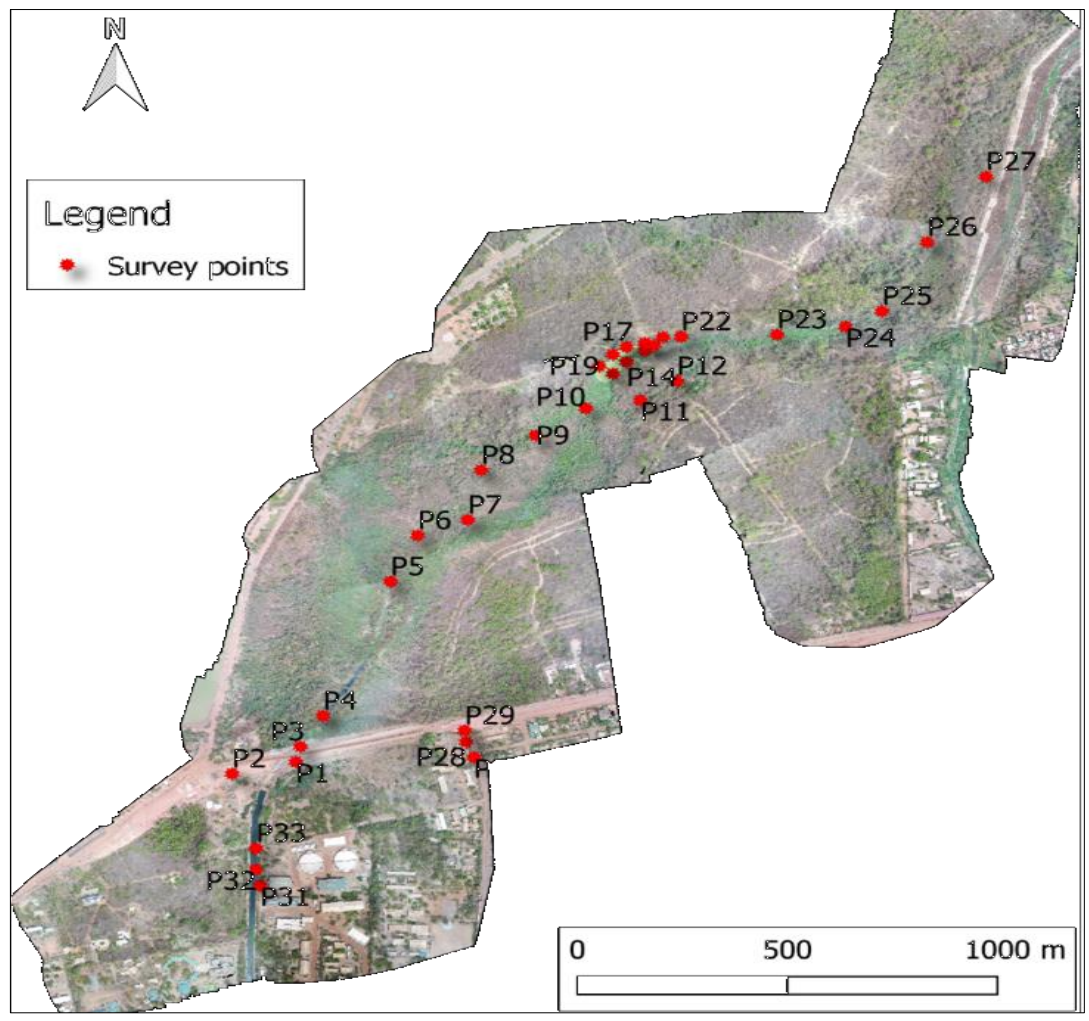

Figure 2: Map showing the study area with the survey points. 


\section{RESULTS}

\section{Evolution of environment conditions}

Before the road construction, the following situation was observed. The UPBW showed globally the situation described in the section "study area". The following remarks can then be noticed. The sacred pond (Kugrisuingo) was wetted and $100 \%$ covered by water jacinth. The RN4 cross the Zogona river, at that point a bridge was constructed. The river under the bridge are free flowing with a high-water level. The part of the Zogona river (upstream the bridge) located in the University Joseph KIZERBO is also free flowing, feed by urban waste water. The first part of the Zogona river (downstream the bridge) is characterized by a rich and dense riparian vegetation.

Four months after the beginning of the roadwork, the following was noticed. To reconstruct the bridge, the Zogona river was blocked for six mouth during the dry season. As a result, the park was no longer receiving water through this channel. This blockage has led to a drying up of the river inside the park. In fact, there was the death of trees which served as a refuge for animals, and the water hyacinth that covered the river, in that same period, no longer exists. The intervention of heavy machinery on the site also causes noise. The nurserymen and other small shopkeepers settled nearby have been evicted. In detail, in the sacred pond it was no longer any water. Then, the aquatic living all died. Upstream the bridge two impoundment was made, one on the Zogona river and the second on the gutter from the Lycee Technique national (LTN). Then the water level became very low under the bridge and they were no longer any continuity of the river flow for six mouth. The section of the Zogona river, upstream the bridge, became stagnant. The riparian forest section in the downstream part of the Zogona river became flooded and flooded tree died after.

\section{Population structure}

Before the road construction, 145 specimens were counted against 202 specimens during the road reconstruction. Figure 3 shows age structure of these crocodile populations during the two periods. Before the roadwork,
Ys were abundant representing $10.24 \%$, hatchlings were also more abundant. During roadwork, it was adult that were more abundant with $37.62 \%$ of the population. Subadults populations shows little variations.

\section{Crocodiles distribution}

Before the road construction, crocodiles were widespread throughout the study area (Figure 4A). They were observed along the river in the park, but their density was higher in the sacred pond and near the Bridge downstream. No crocodile was found upstream the bridge in the Zogona river.

During the roadwork, crocodiles were no longer visible throughout the river (Figure 4B). Low abundance of crocodile populations was observed in the sacred pond inside the park. In contrast, crocodile was more appear in the upstream of the Zogona river up to inside the University Joseph KI-ZERBO. Crocodile were also meet outside the naturel area in the gutter from the LTN. The area between the university's canal and the bridge more crocodile specimens were counted. Most of the specimens found in the park are hatchlings. Other specimens were encountered outside the park. The majority were observed in the University channel. Some were reported in the District "Zone du Bois" and most adults crocodile crossed the road to reach the gutter from the LTN.

Before the roadwork, hatchlings (Figure 5A) and juvenile crocodiles (Figure 5C) were mainly encountered in the sacred pond in the park. During the works, the number of hatchlings (Figure 5B) became very low. With the juveniles (Figure 5D), they are mainly encountered next to the bridge.

The same general pattern is observable for subadults and adults' crocodiles. In fact, the subadults (Figure 6A) and the adults' crocodiles (Figure 6C) were encountered along the river with a strong presence in the pond before the roadwork. During the roadworks, high abundances of subadults (Figure 6B) and adults (Figure 6D) were observed next to the bridge and outside the park mainly in the Zogona river and in the gutter of the Lycee Technique National. 

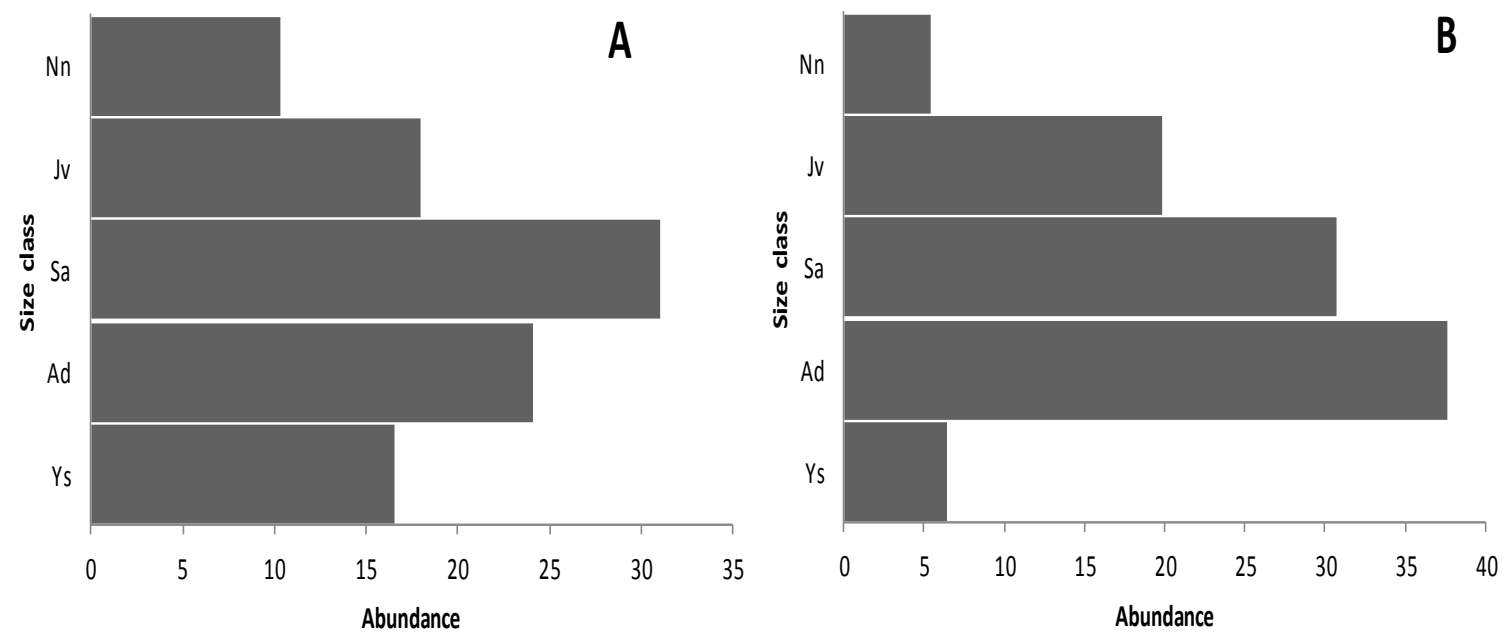

Figure 3: Age (size) structure of crocodile populations before (A) and during (B) roadwork. Nn: hatchlings; Jv: juvenile; SA: subadult; A: adult; Ys: eyes only.
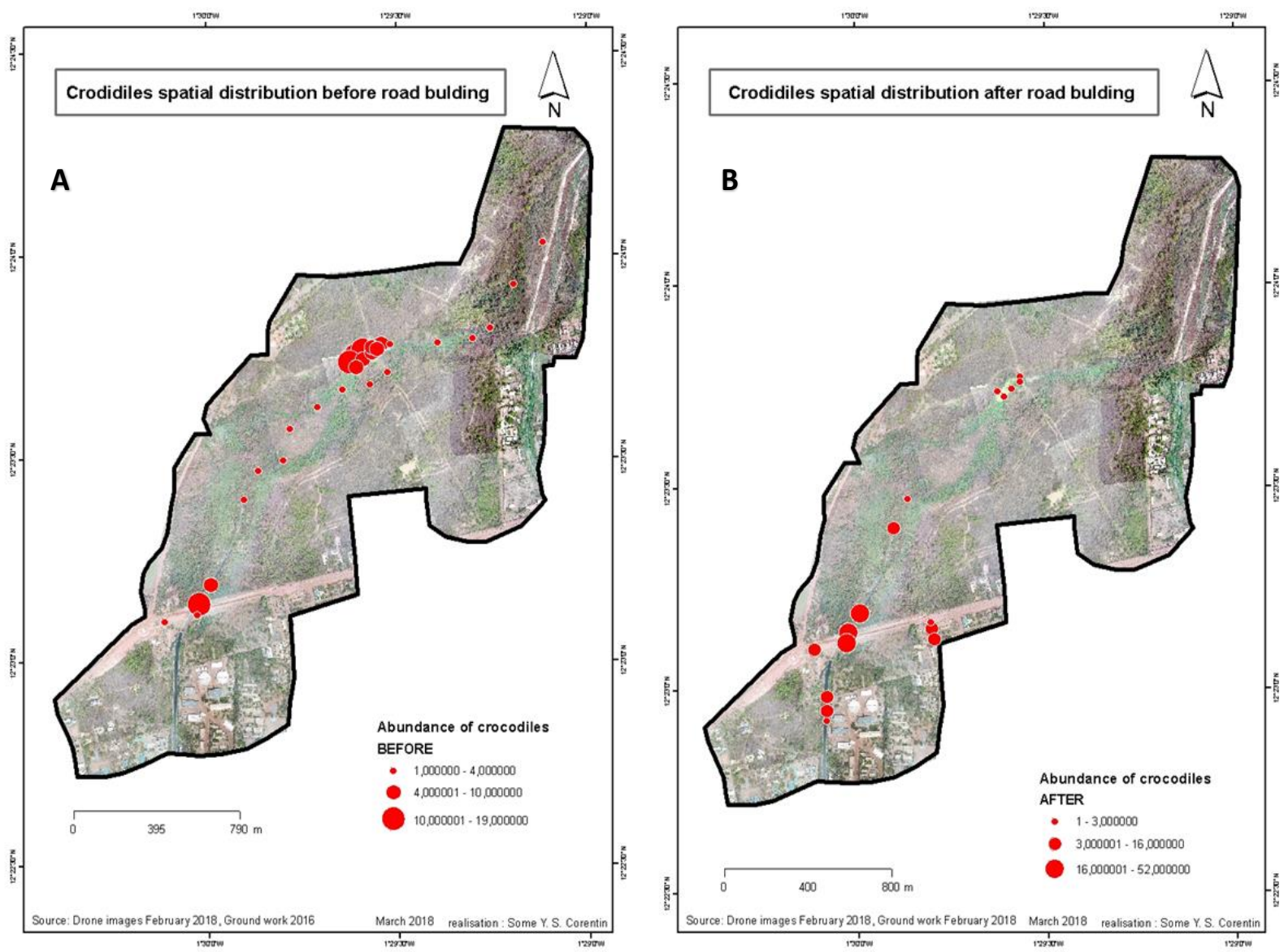

Figure 4: abundance of $C$. suchus before and during road construction. 


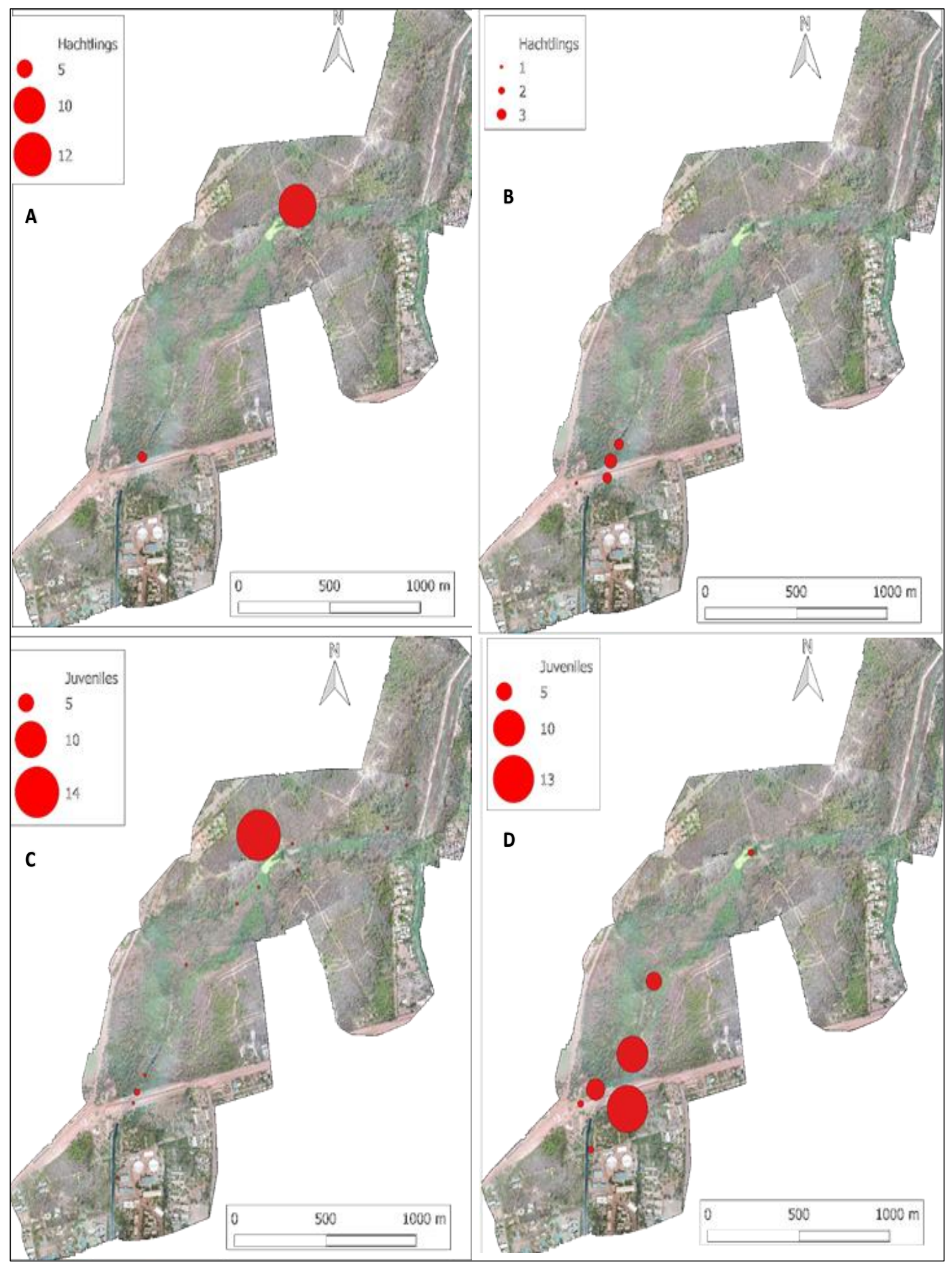

Figure 5: Spatial distribution of $C$. suchus hatchlings and juvenile crocodiles before (A, C) and during (B, D) road construction. 


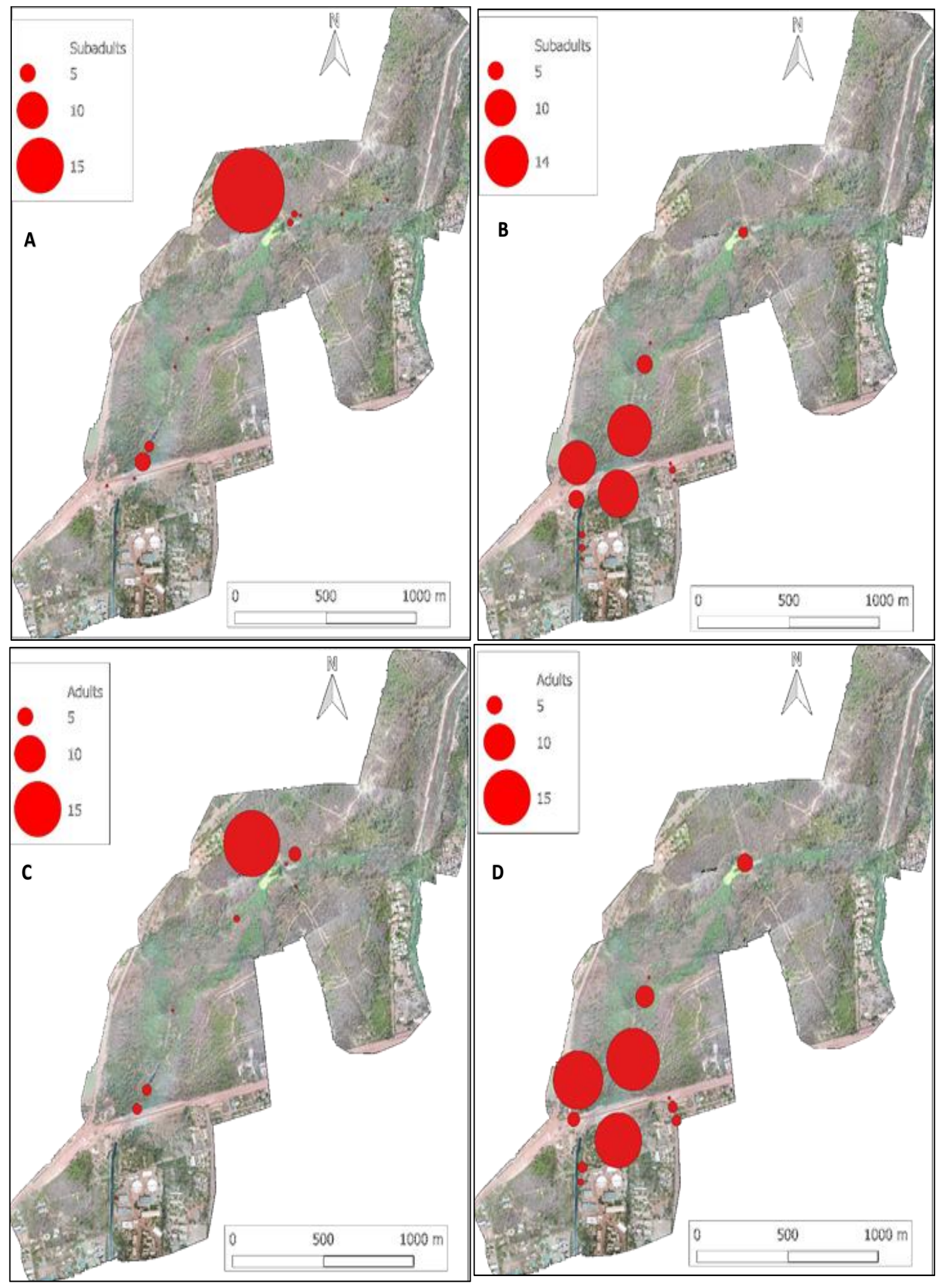

Figure 6: Spatial distribution of $C$. suchus subadults and adults' crocodiles before (A, C) and during (B, D) road construction. 


\section{DISCUSSION}

This study examined the abundance, population structure, and spatial distribution of C.suchus in Urbain Parc Bangr-Weoogo. The UPBW being a protected area, it was a refuge for wildlife, especially in its urban context. According to (Lane 2001; Pretty et al., 2004; Bio-oure et al., 2015; Agbessi et al., 2017), protected areas are today the most natural areas that provide a refuge for wild animals. Then this study confirms the state of the UPBW as important refuge for crocodile. But, despite the protection of the Park, human pressure is very high, caused by more than a million people living nearby (Gnoumou et al., 2008). One of the main perturbations of the UPBW the last decade is the roadwork that begin in 2016. This ongoing roadwork already cause important chances in environmental condition in the UPBW. The chance goes from drought pond, to flooded and died section in the forest. Some impact is also about the flowing of the river that goes through the forest. Then, the connectivity was lost during the roadwork. This situation has led to the destruction of several crocodile habitats leading to their migration to other more favorable, especially to points with permanent water.

This study gives the first data about the crocodiles of the UPBW. Indeed, 145 and 202 individuals were counted, before and during the roadwork. This correspond to 36.72 individuals $/ \mathrm{km}$. This density is important compared to the work of Sai et al. (2016), Botha et al. (2011). Sai et al. (2016) found 82 Nile Crocodiles with encounter rate of 2.28 Nile Crocodiles per $\mathrm{km}$ in the Kove and Sengwa rivers in northwest Zimbabwe. While Botha et al. (2011) found total of 8 crocodiles were found in the whole of the Loskop Dam in South Africa during the 2006 spotlight survey with an encounter rate of 0.11 crocodiles $/ \mathrm{km}$. But in the context of Burkina Faso this density is low compared to others protected area like Bazoule and Sabou were the encounter rate are respectively 76.57 crocodiles $/ \mathrm{km}$ and 54.13 crocodiles $/ \mathrm{km}$ (pers. data). Due to the presence of vegetation (Gnoumou et al., 2008) along the river, it was very difficult to observe crocodiles that disappeared at the slightest sound during the period before roadwork. During roadwork, habitat destruction reported above allowed to see more crocodiles. The same reason stands to explain why we get less proportion of eye only during the roadwork. The high percentage of "eye-only" individuals observed prior to road reconstruction is explained by the fact that many crocodile individuals took advantage of the presence of water and vegetation to disappear as soon as possible they hear the least noise. In contrast, the disturbance of crocodile habitat leads to their migration into secondary habitat, such as the Zogona river and the gutter of the LTN. In that cramped habitat, individual was more exposed, and this allows a good observation of them. The high number of adult crocodiles during the work can also be explained by the ability of adults to move when environmental conditions are not favorable. For example, adults are sometime seen crossing the road while the others size not.

In the UPBW adults and subadults were the most abundant size class. Adults and subadults crocodiles are generally easier to detect because of their size. This result is comparable to studies by Calverley et al. (2014), who had reported higher proportions of subadult and adult crocodiles in lakes and rivers in the Ndumo Game Reserve, South Africa. In contrast, Shirley et al. (2009) have found more juveniles than subadults in their work in Ghana and Côte-d'Ivoire. The population structure of $C$. suchus in the UPBW does not tend towards stability. Because for crocodile populations, the stable class distributions are characterized by a high proportion of juveniles against a low abundance of adult individuals (Bourquin and Leslie, 2011; Wallace et al., 2013).

The high number of hatchlings before the road works could be explained by the follow-up period (May-June). This period, which coincides with the start of the rainy season, corresponds to the crocodile hatching period. While most of the follow-ups during the works take place between September and December. Habitat destruction and the drying up of the central pond during the works could also lead to the death of hatchlings.

Crocodile were also met outside the naturel area in the gutter from the LTN. The road construction has in one way or another 
disrupted the peace of the crocodiles in their natural habitat. It appears that more and more, these reptiles are exposed and roam around the concessions. This situation constitutes a danger for the crocodiles themselves because they can be killed by poachers and even by populations who fear that they will attack them. In addition to that, some people and road users do not hesitate to make a short stop and approach these reptiles to observe them and take some photo shots. This is not without consequences because crocodiles are stressed. This can lead to the risk of human attacks. Domestic animals are also exposed to attacks by crocodiles which roam around the concessions. All of this increase risks of Human-crocodile conflicts in this area.

According to Gravel et al. (2012), roads construction can constitute a barrier for the movement of certain animals such as amphibians. Roads are a marginal quality habitat because of noise, substances and particles projected by the passage of vehicles (Villard et al., 2012). Although more difficult to quantify, the indirect effects of roads on wildlife should be treated, at least, in the same way as road deaths, especially for species such as reptiles. This can lead to more or less permanent fragmentation of their populations (Villard et al., 2012; Brzezinski et al., 2012; Gravel et al., 2012). Road work can also lead to crocodile death as they cross the road. This was confirmed by the work of Mazerolle et al., 2005 , who found that roads are not just a barrier to animals, but can be particularly deadly for small animals such as reptiles and amphibians. This situation of loss of habitats can lead to the disappearance of crocodiles. However, these reptiles play a very important socioeconomic role for the populations (Tiogue et al., 2016).

\section{Conclusion}

This study examined the consequences of road reconstruction on the distribution of $C$. suchus and the mapping of its potential habitat in the UPBW before and during the construction of the RN4 road in the city of Ouagadougou. The distribution of $C$. suchus recorded in the pond and other channels was not uniform. The crocodiles were spread all along the river in the Park, but the reconstruction of the road modified this distribution. This has led many crocodiles, mostly adults, to migrate to other more suitable areas. This migration of crocodiles in the secondary channels is not without consequence on the life of these reptiles and also on the Human-Crocodile relations. It would be interesting to identify the direct and indirect effects of road reconstruction on the migration of reptiles and crocodiles before any activity, in order to mitigate the impact of roads.

\section{COMPETING INTERESTS}

The authors declare that they have no competing interests.

\section{AUTHORS' CONTRIBUTIONS}

IO and NWK conceived and designed the study under the supervision of AO and IO. Thereby, IO, VB and JK performed the fieldwork. Data analysis and manuscript editing were done by $\mathrm{IO}$ assisted by $\mathrm{AO}$ and IO. All the work was done under the supervision of GBK who is the director of the laboratory

\section{ACKNOWLEDGMENTS}

We thank anonymous reviewers for many insightful comments and suggestions which largely helped to improve the manuscript. This study was performed with financial support of the projects "Africa For Innovation, Mobility, Exchange, Globalization and Quality" (AFIMEGQ).

\section{REFERENCES}

Agbessi KGE, Ouedraogo M, Camara M, Segniagbeto H, Houngbedji MB, Kabre AT. 2017. Distribution spatiale du singe à ventre rouge, Cercopithecus erythrogaster erythrogaster Gray et les menaces pesant sur sa conservation durable au Togo. Int. J. Biol. Chem. Sci., 11(1): 157-173. DOI: http://dx.doi.org/10.4314/ijbcs.v11i1.13.

Alroy J. 2015. Current Extinction Rates of Reptiles and Amphibians. Proceedings of the National Academy of Sciences, 112(42): 13003-13008. DOI: https://doi.org/10.1073/pnas.1508681112

Andrews KM, Gibbons JW. 2005. How do highways influence snake movement? 
Behavioral responses to roads and vehicles. Copeia, 2005(4): 772-782. DOI: https://doi.org/10.1643/0045-

8511(2005)005

[0772: HDHISM]2.0.CO;2.

Belem M, Zoungrana M, Nabaloum M. 2018. Les effets combinés du climat et des pressions anthropiques sur la forêt classée de Toéssin, Burkina Faso. Int. J. Biol. Chem. Sci., 12(5): 2186-2201. DOI: https://dx.doi.org/10.4314/ijbcs.v12i5.20

Bio-oure R, Daouda AH, Kindomihou MV, Mensah GA. 2015. Inventaire, structure morpho-métrique et importance des varans sacrés de Kandi (Nord-Est Bénin). Int. J. Biol. Chem. Sci., 9(6): 2663-2675. DOI:

http://dx.doi.org/10.4314/ijbcs.v9i6.12.

Botha H, Van-Hoven W, Guillette LJ. 2011. The decline of the Nile crocodile population in Loskop Dam, Olifants River South Africa. Water SA, 37(1): 103108. DOI: $10.4314 /$ wsa. v37i1.64109.

Bourquin SL, Leslie AJ. 2011. Estimating demographics of the Nile Crocodile $(C$. niloticus Laurenti) in the panhandle region of the Okavango Delta, Botswana. African Journal of Ecology, $\mathbf{5 0}: 1-8$. DOI: https://doi.org/10.1111/j.13652028.2011.01285.x.

Brzeziński M, Eliava G, Żmihorski M. 2012. Road mortality of pond-breeding amphibians during spring migrations in the Mazurian Lakeland, NE Poland. Eur J Wildl Res, 58: 685-693. DOI: 10.1007/s10344-012-0618-2.

Calverley PM, Downs CT. 2014. Population status of Nile Crocodiles in Ndumo Game Reserve, Kwazulu-Natal, South Africa (1971-2012). Herpetologica, 70 (4): 417425.

DOI:

https://doi.org/10.1655/herpetologica-D13-00090.

Caro T. 2015. Roads through national parks: a successful case study. Tropical Conservation Science, 8(4): 1009-1016. DOI: 10.1177/194008291500800411.

Ceballos G, Ehrlich PR, Barnosky AD, García A, Pringle RM, Palmer TM. 2015. Accelerated Modern Human-Induced Species Losses: Entering the Sixth Mass Extinction. Science Advances, 1(5): e1400253.

DOI:

10.1126/sciadv.1400253.

Fukuda Y, Saalfeld K, Webb G, Manolis C, Risk R. 2013. Standardized methods of spotlight surveys for crocodiles in the tidal rivers of the Northern Territory, Australia. Northern Territory Naturalist, 2013(24): 14-32.

Gnoumou A, Thiombiano A, Hahn-hadjali K, Abadouabou B, Sarr M, Guinko S. 2008. Le Parc Urbain Bangr-Wéoogo : une aire de conservation de la diversité floristique au cœur de la ville de Ouagadougou, Burkina Faso. Flora et Vegetatio SudanoSambesica, 11 : 35-48. DOI : http://dx.doi.org/10.15560/7.1.85.

Gravel M, Mazerolle MJ, Villard MA. 2012. Interactive effects of roads and weather on juvenile amphibian movements. Amphibia-Reptilia. 33(2012): 113-127. DOI: $10.1163 / 156853812 \times 625512$.

Hanski I. 2005. Landscape Fragmentation, Biodiversity Loss and the Societal Response. The longterm consequences of our use of natural resources may be surprising and unpleasant. $E M B O$ reports, 6(5): 388-392. DOI: https://doi.org/10.1038/sj.embor.740039 8.

Hekkala E, Shirley MH, Amato G, Austin JD, Charter S, Thorbjarnarson J, Vliet KA, Houck ML, Desalle R, Blum MJ. 2011. An ancient icon reveals new mysteries: mummy DNA resurrects a cryptic species within the Nile crocodile. Molecular Ecology. DOI: $\quad 10.1111 / \mathrm{j} .1365-$ 294X.2011.05245.x.

Kangoyé NM, Oueda A, Ouédraogo I, Guenda W. 2016. Hippotragus equinus (É. Geoffroy Saint-Hilaire, 1803) and Kobus ellipsiprymnus defassa (Rüppell, 1835) diet in semi-captivity in the urban park Bangr-Weoogo (Burkina Faso). Int. J. Biodivers. Conserv., 8(4): 72-80. DOI : 10.5897/IJBC2015.0920.

Koadima M, Sarr M. 2010. Le parc urbain Bangr-Weoogo. Allons en brousse en plein cœur de Ouagadougou. In Atlas de la Biodiversité de l'Afrique de l'Ouest, Tome II : Burkina Faso, Thiombiano A, Kampann D (eds). Frankfurt/Main : Ouagadougou ; 376-377. 
Krauss J, Bommarco R, Guardiola M, Heikkinen RK, Helm A, Kuussaari M, Lindborg R, Öckinger E, Pärtel M, Pino J, Pöyry J, Raatikainen KM, Sang A, Teder T, Zobel M, Steffan-Dewenter I. 2010. Habitat Fragmentation Causes Immediate and Time-Delayed Biodiversity Loss at Different Trophic Levels. Ecology Letters, 13(5): 597-605. DOI: $10.1111 / \mathrm{j} .1461-$ 0248.2010.01457.x.

Lane MB. 2001. Affirming new directions in planning theory: comanagement of protected areas. Society and Natural Resources, 14(8): 657-671. DOI: 10.1080/08941920118212.

Mazerolle MJ, Huot M, Gravel M. 2005. Behavior of amphibians on the road in response to car traffic. Herpetologica, 61(4): $\quad 380-388 . \quad$ DOI: https://doi.org/10.1655/04-79.1.

Platt SG, Thorbjarnarson JB. 2000. Population status and conservation of Morelet's crocodile, Crocodylus moreletii, in northern Belize. Biological Conservation, 96(1): 21-29: DOI: $10.1016 / S 0006-$ 3207(00)00039-2.

Pretty J, Smith D. 2004. Social capital in biodiversity conservation and management. Conservation Biology, 18(3): 631-638. DOI: http://dx.doi.org/10.1111/j.15231739.2004.00126.

Ramsar. 2019. Fiche descriptive Ramsar pour le Site ${ }^{\circ}$ 2367, Complexe du Parc Urbain Bãngr-Wéoogo et du lac des trois barrages, Burkina Faso. SISR V.1.6. https://rsis.ramsar.org/ris/2367.

Sai M, Utete B, Chinoitezvi E, Moyo GH, Gandiwa E. 2016. A Survey of the Abundance, Population Structure, and Distribution of Nile Crocodiles (Crocodylus Niloticus) Using Day Ground Surveys in Sengwa Wildlife Research Area, Zimbabwe. Herpetological Conservation and Biology, 11: 426-433.

Santiapillai C, De-Silva M. 2001. Status, distribution and conservation of crocodiles in Sri Lanka, Biological
Conservation, 97(3): 305-318. DOI: 10.1016/S0006-3207(00)00126-9.

Shirley MH, Eaton MJ. 2012. Procédures Standard de Suivi des Populations de Crocodiles. Groupe Spécialiste de Crocodiles : Darwin: www.iucncsg.org/pages/Publications.ht $\mathrm{ml}$.

Shirley MH, Oduro W, Beibro HY. 2009. Conservation status of crocodiles in Ghana and Cote d'Ivoire, West Africa. Fauna and Flora International Oryx, 43(1): $\quad 136-145 . \quad$ DOI: 10.1017/S0030605309001586.

Shirley MH, Vliet KA, Carr AN, Austin JD. 2014. Rigorous approaches to species delimitation have significant implications for African crocodile systematics and conservation. Proceedings of the Royal Society. B: Biological Sciences, 281(1776): 20132483. DOI: 10.1098/rspb.2013.2484.

Tiogue CT, Tomedi-tabi ME, Etaba DA, Makongo FDN. Caractérisation sociotechnico-économique de la pêche artisanale du crocodile Nain africain Osteolaemus tetraspis (Cope, 1861) dans l'arrondissement de Yabassi, Littoral Cameroun. Int. J. Biol. Chem. Sci., 10(3): 1027-1036.

DOI: http://dx.doi.org/10.4314/ijbcs.v10i3.10.

Trombulak SC, Frissell CA. 2000. Review of Ecological Effects of Roads on Terrestrial and Aquatic Communities. Conservation Biology, 14(1): 18-30. DOI: 10.1046/j.1523-1739.2000. 99084.x.

Villard MA, Mazerolle MJ, Haché S. 2012. L'impact des routes, au-delà des collisions : le cas des oiseaux forestiers et des amphibiens. Le Naturaliste Canadien, 136(2): 61-65. DOI : https://doi.org/10.7202/1009108.

Wallace KM, Leslie AJ, Coulson T, Wallace AS. 2013. Population size and structure of the Nile Crocodile ( $C$. niloticus) in the lower Zambezi Valley. International Journal of Fauna and Flora Oryx, 47(3): 457-465.

DOI: https://doi.org/10.1017/S0030605311001 712. 